As-Syifaa Jurnal Farmasi Desember 2020;12(2):150-157.

ISSN : 2502-9444 (electronic); 2085-4714 (printed)

Journal Homepage : http://jurnal.farmasi.umi.ac.id/index.php/as-syifaa

\title{
FORMULASI DAN EVALUASI FISIK SEDIAAN KAPSUL EKSTRAK DAUN CINCAU HIJAU (Cyclea barbata Miers ) SEBAGAI ANTI INFLAMASI
}

\section{Fitria Wulandari, Fitri Wahyu Widyawati, Khusnul Rizaldi, Fauzia Ningrum Syaputri}

\author{
Farmasi Universitas Muhammadiyah Bandung \\ Email: fitriawulandari.9j@gmail.com
}

\begin{abstract}
One of the Indonesian plants that can be used is green grass jelly leaf (Cyclea barbata Miers) because it contains alkaloids, polyphenols, saponins and flavonoids that can prevent inflammation. Inflammation is an environmental physiological response caused by damage or damage to the tissue that functions, reduces, or confines an injuring agent or injured tissue. The purpose of this study was to formulate green grass jelly leaf extract into anti-inflammatory capsules. This research begins with the maceration of the simplicia extraction process of green grass jelly leaves using ethanol $96 \%$ solvent. Granule preparation used dry granulation method with vivapur 101 which varied in 3 formulas, namely (1:1, 1:1,5, 1:2). The next step was a physical evaluation test of granules including moisture content, flow properties, angle of rest, carcass index, compressible density and true density and a physical evaluation test including organoleptic test, weight uniformity and disintegration time. The results of the evaluation test that have been carried out show that formula 3 with a thick extract concentration: vivapur 101 (1:2) is the most optimal, because it meets the evaluation test requirements with a moisture content value of dry extract granules $1.5 \%$ and a water content value of granule capsules. green grass jelly leaves $1.1 \%$.
\end{abstract}

Key Words: Green grass jelly leaves, capsules, granules, moisture content.

\section{PENDAHULUAN}

Inflamasi adalah respon fisiologis setempat yang ditimbulkan oleh cedera atau kerusakan jaringan, yang berfungsi menghancurkan, mengurangi, atau menghilangkan suatu agen pencedera maupun jaringan yang cedera itu. Gejala respon inflamasi meliputi rubor (kemerahan), kalor (panas), dolor (nyeri), turgor (pembengkakan). Pengobatan yang selama ini dilakukan untuk memperlambat atau membatasi proses kerusakan jaringan yang terjadi pada daerah inflamasi menggunakan obat berbahan dasar kimia, yaitu obat anti inflamasi nonsteroid (AINS) yang memiliki efek samping pada saluran cerna diantaranya menyebabkan tukak lambung. Oleh karena itu pemanfaatan tumbuhan obat dengan khasiat sebagai antiinflamasi perlu dilakukan untuk menemukan pengobatan alternatif dengan efek samping yang relatif lebih kecil. Salah satu tumbuhan di Indonesia yang sejak dahulu digunakan untuk pengobatan adalah cincau hijau (Cyclea barbata Miers) dari Famili Menispermaceae. ${ }^{1}$

Cincau hijau (Cyclea barbata Miers) yang berasal dari Famili Menispermaceae memiliki kandungan kimia aktif yaitu klorofil, karbohidrat, alkaloid siklein, tetrandin, dimetil tetrandin, polifenol, saponin, dan flavonoid. ${ }^{2}$ Daun cincau hijau diketahui mengandung klorofil, serta senyawa bioaktif polifenol, saponin, flavonoid dan lemak. Keempat komponen tersebut secara umum dikenal 
sebagai antioksidan, antikanker, dan

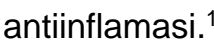

Flavanoid merupakan senyawa yang memiliki aktivitas farmakologi sebagai antiinflamasi dengan menurunkan jumlah leukosit dan mengurangi aktivitas komplemen sehingga menurunkan adhesi leukosit ke endotel dan mengakibatkan penurunan respon inflamasi. Hasil penelitian sebelumnya diketahui bahwa ekstrak etanol daun cincau hijau (Cyclea barbata Miers) memiliki efek sebagai anti inflamasi. Ekstrak etanol daun cincau hijau (Cyclea barbata Miers) yang paling efektif ialah pada konsentrasi $7,5 \mathrm{mg} / \mathrm{kgBB}$ dengan persen penurunan 36,75 \%. Daun cincau hijau telah lama dijadikan bahan baku minuman cincau yang dipercaya berkhasiat untuk mengobati demam, sakit perut atau lambung, radang, serta dapat menurunkan tekanan darah dan mengatasi panas dalam. ${ }^{1}$

Fenomena penggunaan daun cincau hijau dimasyarakat sebagai anti inflamasi masih menggunakan cara tradisional yaitu dengan cara mengambil beberapa helai daun cincau hijau lalu diremas-remas kemudian direbus hingga air rebusan berwarna hijau, lalu air rebusan tersebut diminum secara rutin, namun dengan cara tersebut memiliki keterbatasan yaitu rasa yang tidak enak dan bau yang khas dari bahan alam, air rebusan dalam jangka waktu yang lama dapat rusak karena mikroorganisme, dan preparasi membutuhkan waktu yang lama, sehingga untuk meningkatkan efisiensi dan memaksimalkan efek terapi daun cincau hijau sebagai anti inflamasi maka perlu dibuat inovasi pengembangan produk farmasi.

Salah satu sediaan farmasi yang dipilih adalah kapsul karena dapat menutupi rasa dan bau yang tidak enak, mudah untuk dikonsumsi, mudah dalam penyiapan dan bahan obat terlindung dari pengaruh luar (cahaya, kelembapan). ${ }^{3} \quad$ Formulasi serbuk sering membutuhkan penambahan zat pengisi, lubrikan, dan glidan pada bahan aktif untuk mempermudah proses pengisian kapsul. ${ }^{4}$

\section{METODE PENELITIAN}

\section{Alat dan Bahan}

Alat yang digunakan yaitu Vacum rotary evaporator, bejana maserasi, blender, cawan porselen, mortir dan stamper, penangas air, timbangan analitis, beaker glass, gelas ukur, sudip, kaca arloji, gelas ukur, batang pengaduk, oven dan lemari pendingin, moisture balance. Bahan yang digunakan dalam penelitian ini adalah daun cincau hijau, etanol $70 \%$, vivapur 101, talk, magnesium stearat, aerosil, amilum jagung, dan cangkang kapsul gelatin.

\section{Prosedur Penelitian}

\section{Pembuatan ekstrak kental daun cincau hijau dengan metode maserasi}

Serbuk daun cincau hijau ditimbang sebanyak 150 gram, kemudian dimasukan kedalam wadah kaca dan direndam dengan etanol $96 \%$ sebanyak 1,5 liter, didiamkan selama 24 jam sambil sesekali diaduk, lalu disaring dan diuapkan menggunakan waterbath dengan suhu $60^{\circ} \mathrm{C}$, sampai diperoleh ekstrak kental.

\section{Pembuatan Ekstrak Kering}

Ekstrak kental (3gr) ditambah vivapur 101 (3gr), digerus hingga homogen, kemudian dikeringkan mengguakan dry oven selama 30 menit dengan suhu $50 \circ \mathrm{C}$, lalu ditentukan nilai moisture content serbuk kering.

\section{Formulasi Sediaan Kapsul}

Semua bahan ditimbang sesuai dengan konsentrasi dalam formula $(1,2$, dan 3). Masukan amilum jagung, aerosil, dan 
ekstrak kering kedalam mortir diaduk hingga homogen, kemudian tambahkan magnesium stearat dan talk aduk hingga homogen, lalu keringkan mengunakan dry oven selama 30 menit dengan suhu $50{ }^{\circ} \mathrm{C}$,lalu diayak dan ditentukan nilai moisture content kemudian diayak kembali dan dimasukan kedalam cangkang kapsul.

Tabel 1.Variasi formulasi kapsul ekstrak daun cincau hijau

\begin{tabular}{|c|c|c|c|c|}
\hline \multirow{2}{*}{ No } & \multirow{2}{*}{ Nama Bahan } & \multicolumn{3}{|c|}{ Formula } \\
\hline & & F1 & F2 & F3 \\
\hline 1 & Ekstrak daun cincau hijau & $1,2 \mathrm{mg}$ & $1,2 \mathrm{mg}$ & $1,2 \mathrm{mg}$ \\
\hline 2 & Vivapur 101 & $1,5 \mathrm{mg}$ & $2 \mathrm{mg}$ & $2,5 \mathrm{mg}$ \\
\hline 3 & Aerosil & $3 \%$ & $3 \%$ & $3 \%$ \\
\hline 4 & Talk & $2 \%$ & $2 \%$ & $2 \%$ \\
\hline 5 & Mg.Stearat & $1 \%$ & $1 \%$ & $1 \%$ \\
\hline 6 & Amylum Jagung & Ad $100 \%$ & Ad $100 \%$ & Ad $100 \%$ \\
\hline 7 & Bobot per kapsul & 150 mg & 150 mg & $150 \mathrm{mg}$ \\
\hline
\end{tabular}

\section{HASIL DAN PEMBAHASAN}

Kapsul adalah sediaan padat yang terdiri obat cangkang keras atau lunak yang dapat larut,cangkang umumnya terbuat dari gelatin bisa juga pati atau bahan lain yang sesuai. ${ }^{4}$ Pembuatan ekstrak dalam penelitian ini menggunakan metode maserasi, Maserasi merupakan proses pengekstrakan dengan menggunakan pelarut dengan beberapa kali pengocokan atau pengadukan pada temperatur ruang. ${ }^{5}$

Tujuan menggunakan metode maserasi ialah untuk menghindari penguapan atau kerusakan zat yang tidak tahan panas . Proses maserasi dilakukan dengan merendam 150 gram simplisia dengan 1,5 liter etanol 96\% dalam toples kaca. Alasan penggunaan pelarut etanol 96\% karena bersifat lebih selektif yaitu hanya menarik zat berkhasiat yang dikehendaki, absorbsinya baik dan mendapatkan ekstrak kental lebih cepat. $^{6}$ Menurut penelitian ${ }^{7}$, diketahui bahwa zat aktif yang terdapat didalam serbuk daun cincau hijau dapt tersari oleh etanol 96\%. Kemudian ekstrak didiamkan selama 24 jam sambil sesekali diaduk, lalu disaring dan diuapkan menggunakan waterbath.

\section{Formulasi Granul}

Metode pembuatan granul terdiri dari granulasi basah dan granulasi kering. Penelitian ini menggunakan metode granulasi kering karena dosis dari zat aktif yang terlau kecil sehingga sulit untuk dikempa langsung dan juga zat aktif yang sensitif terhadap lembab jadi tidak mungkin menggunakan metode granulasi basah. ${ }^{8}$ Pada granulasi kering penggranulan tanpa menggunakn eksipien yang berupa cairan, semua komponen kering . Kelebihan metode granulasi kering ialah peralatan yang diperlukan lebih sedikit, cocok digunakan pada zat aktif yang tidak tahan panas, tahap pengerjaan yang tidak terlalu lama biaya lebih efisien, mempercepat waktu hancur obat. ${ }^{9}$ Tujuan metode granulasi adalah untuk memperoleh granul yang dapat mengalir bebas.

Proses pembuatan granul ekstrak daun cincau hijau dengan cara mencampurkan ekstrak kental (3 gr) ditambah vivapur 101 (3 gr) untuk formula 1 , sedangkan untuk formula 2 mencampurkan ekstrak kental (3gr) ditambah vivapur 101 (4,5 gr), lalu untuk formula 3 mencampurkan ekstrak kental (3 gr) ditambah vivapur 101 (6 gr) digerus hingga homogen, 
kemudian dikeringkan mengguakan dry oven selama 30 menit dengan suhu $50 \circ \mathrm{C}$, lalu ditentukan nilai mosture content dari serbuk kering.

Hasil dari proses pengeringan ini didapat penurunan kadar air yang cukup tinggi pada formula 3 menghasilkan serbuk kering, halus, mudah homogen dan stabil, karena jumlah vivapur yang ditambahkan kedalam formula 3 paling banyak, sedangkan untuk formula 1 kadar air sebesar $4,1 \%$ dan formula 1 sebesar $4,0 \%$, hal ini sesuai dengan persyaratan kadar air granul yaitu sebesar $2-5 \% .^{10}$

Tabel 2. Hasil Moisture Content Granul Ekstrak Daun Cincau Hijau

\begin{tabular}{ccccc}
\hline \multirow{2}{*}{ No } & \multirow{2}{*}{ Formula } & \multicolumn{2}{c}{ Perbandingan } & \multirow{2}{*}{ MC } \\
\cline { 3 - 4 } & & Ekstrak kental & Vivapur $\mathbf{1 0 1}$ & \\
\hline 1 & F1 & 1 & 1 & $4,1 \%$ \\
2 & F2 & 1 & 1,5 & $4,0 \%$ \\
3 & F3 & 1 & 2 & $1,5 \%$ \\
\hline
\end{tabular}

Setelah itu granul ekstrak kering dicampur dengan amylum jagung, didalam mortir homogenkan lalu tambahkan aerosil, magnesium stearat, dan talk homogenkan kemudian diayak menggunakn pengayak lalu ditimbang bobot awal granu, setelah utu dikeringkan menggunakan dry oven selama 30 menit dengan suhu $50 \mathrm{C}$ dan ditentukan nilai moisture content dari serbuk kering. Penambahan magnesium stearat yang berfungsi sebagai lubrikan untuk mengurangi gesekan antara cangkang kapsul. Amylum Jagung yang berfungsi sebagai pengisi yaitu untuk mengisi masa kapsul yang digunakan dan juga digunakan untuk menetapkan berat sediaan yang akan diproduksi dan memperbaiki lajur alir. Aerosil yang berfungsi sebagai adsorben untuk mengatur laju alir granul dan mengurangi gesekan antar partikel. Talk berfungsi sebagai glidan atau pelican.

Tabel 3. Nilai Moisture Content Granul Kapsul Daun Cincau Hijau

\begin{tabular}{ccccc}
\hline No & Formula & Bobot Awal & Bobot Akhir & MC \\
\hline 1 & Formula 1 & $14.114,3 \mathrm{mg}$ & $13.667,8 \mathrm{mg}$ & $3,1 \%$ \\
2 & Formula 2 & $14.380,1 \mathrm{mg}$ & $13.722,6 \mathrm{mg}$ & $4,5 \%$ \\
3 & Formula 3 & $14.422,8 \mathrm{mg}$ & $14.253,8 \mathrm{mg}$ & $1,1 \%$ \\
\hline
\end{tabular}

Pada tahap ini didapatkan hasil semua formula memiliki \% kadar air yang rendah atau dibawah 5\%. Dari Tabel 3 diatas formula 3 memiliki kadar air yang paling rendah karena penambahan vivapur yang cukup banyak sehingga air yang dapat diserap oleh vivapur pun banyak. Semua formula diatas dapat langsung dimasukan kedalam cangkang kapsul untuk selanjutnya dilakukan uji evaluasi.

\section{Evaluasi Granul}

Evaluasi granul perlu dilakukan untuk menilai kualitas dari granul dan dapat dijadikan tolak ukur kelayakan suatu granul untuk dimasukan kedalam cangkang kapsul. Evaluasi granul yang dilakukan meliputi uji kadar lembab, kerapatan mampat, kerapatan sejati, uji sifat alir meliputi uji waktu alir, uji sudut diam, indeks pengetapan dan Housner Ratio. ${ }^{11}$ Hasil evaluasi granul dapat dilihat pada Tabel 4. 


\section{Kandungan lembab granul}

Kandungan lembab dari suatu granul perlu dievaluasi untuk memastikan bahwa granul yang dihasilkan memiliki kandungan lembab yang memenuhi persyaratan. Kandungan air sisa dalam granul berguna untuk mengaktifkan kembali sifat atau fungsi bahan pengikat di samping untuk mencegah timbulnya muatan elektrostatik. Granul apabila terlalu lembab akan menghasilkan sifat alir yang buruk. Sebaliknya granul yang terlalu kering akan menghasilkan tablet yang rapuh dan kekerasan yang minimal. ${ }^{11}$
Penggunaan aerosil dapat menahan sejumlah cairan tanpa menyebabkan basah dengan kata lain dapat membantu mengeringkan ekstrak. Penelitian ini menggunakan alat dengan metode gravimetri untuk menentukan kandungan lembab dar granul, Syarat kelembaban granul yang baik ialah 2-5\%. Hasil Uji Evaluasi menyatakan bahwa semua Formulasi memenuhi syarat kelembaban granul yaitu untuk formula 1 sebesar $3,1 \%$, formula 2 sebesar $4,5 \%$ dan untuk formula 3 sebesar 1,1\% yang artinya granul dapat dibuat sediaan kapsul karena tidak akan merusak cangkang kapsul. ${ }^{12}$

Tabel 4. Hasil Uji Evaluasi Granul Ekstrak Daun Cincau Hijau

\begin{tabular}{clcccc}
\hline No & Uji Evaluasi Sediaan & F1 & F2 & F3 & Syarat \\
\hline 1 & Moisture Content & $3,1 \%$ & $4,5 \%$ & $1,1, \%$ & $2-5 \%$ \\
2 & Waktu Alir & $1,635 \mathrm{~g} / \mathrm{s}$ & $1,9 \mathrm{~g} / \mathrm{s}$ & $7,78 \mathrm{~g} / \mathrm{s}$ & $>4 \mathrm{~g} / \mathrm{s}$ \\
3 & Sudut Istirahat & $15,21^{\circ}$ & $17,17^{\circ}$ & $15,21^{\circ}$ & $<25^{\circ}$ \\
4 & Kerapatan Mampat & $0,79 \mathrm{~g} / \mathrm{ml}$ & $0,625 \mathrm{~g} / \mathrm{ml}$ & $0,623 \mathrm{~g} / \mathrm{ml}$ & $>0,21 \mathrm{~g} / \mathrm{ml}$ \\
5 & Kerapatan Sejati & $0,425 \mathrm{~g} / \mathrm{ml}$ & $1,266 \mathrm{~g} / \mathrm{ml}$ & $1,276 \mathrm{~g} / \mathrm{ml}$ & $>0,21 \mathrm{~g} / \mathrm{ml}$ \\
6 & Indeks Kars & $85,29 \%$ & $32,4 \%$ & $31,7 \%$ & $5-11 \%$ \\
7 & Housner ratio & $1,212 \mathrm{~g} / \mathrm{ml}$ & $1,482 \mathrm{~g} / \mathrm{ml}$ & $1,464 \mathrm{~g} / \mathrm{ml}$ & $>1 \mathrm{~g} / \mathrm{ml}$ \\
\hline
\end{tabular}

\section{Sifat alir granul}

Parameter lain untuk menilai kualitas granul yang dihasilkan ialah sifat alir granul. Waktu alir yaitu waktu yang diperlukan untuk mengalirkan sejumlah granul pada suatu alat. Kecepatan alir dipengaruhi oleh bentuk, ukuran, kondisi permukaan, kelembaban granul dan penambahan bahan pelicin. ${ }^{12}$ Kecepatan alir dipengaruhi oleh bentuk, ukuran, kondisi permukaan,kelembaban granul dan penambahan bahan pelican apabila granul mempunyai sifat alir yang baik. campuran granul dikatakan memiliki sifat alir yang baik jika kecepatan alirnya tidak kurang dari 10 $\mathrm{g} /$ detik atau $100 \mathrm{~g}$ granul waktu alirnya tidak lebih dari 10 detik. Granul yang digunakan pada pengujian ini sebanyak $25 \mathrm{~g}$ sehingga granul yang baik memenuhi persyaratan bila waktu alirnya kurang dari 2,5 detik atau kecepatan alirnya tidak kurang dari $10 \mathrm{~g} /$ detik. Sifat alir dapat diukur dengan metode langsung (uji waktu alir) dan metode tidak langsung (uji sudut diam dan indeks pengetapan $)^{13}$

Hasil uji evaluasi sifat alir menyatakan bahwa semua formula memnuhi syarat sifat alir yaitu untuk formula 1 sebesar $1,635 \mathrm{~g} / \mathrm{s}$ lalu formula 2 sebesar $1,9 \mathrm{~g} / \mathrm{s}$ dan untuk formula 3 sebesar $7,78 \mathrm{~g} / \mathrm{s}$ granul menunjukan hasil evaluasi memenuhi parameter laju alir granul dibawah $10 \mathrm{~g} / \mathrm{s}$, formula 1 yang memiliki waktu alir paling cepat hal ini terjadi karena vivpaur yang ditambahkan paling sedikit sedangkan untuk formula 3 waktu alir yang dihasilkan lebih lama krena vivapur yang ditambahkan cukup 
banyak. Penambahan vivapur yang cukup banyak akan mempengaruhi sifat alir granul walaupun granul sudah ditambahkan aerosil yang bisa berfungsi sebagai pelicin dengan jumlah yang sama tiap formulanya. ${ }^{14}$

Sifat aliran dipengaruhi oleh ukuran dan bentuk partikel ukuran yang lebih besar dan bulat menunjukkan aliran yang lebih baik. Kecepatan aliran maksimum dicapai setelah aliran menurun apabila ukuran partikel mendekati ukuran lubang. Kadangkadang, aliran buruk dapat disebabkan oleh adanya lembab. Dalam hal ini, pengeringan serbuk akan mengurangi kohesivitas serbuk. ${ }^{8}$

\section{Sudut Diam}

Sudut diam yaitu sudut tetap yang terjadi antara timbunan partikel bentuk kerucut dengan bidang horizontal. Besar kecilnya sudut diam dipengaruhi oleh bentuk, ukuran dan kelembaban granul. Bila sudut diam lebih kecil dari $25^{\circ}$ biasanya menunjukan bahwa bahan dapat mengalir bebas, bila sudutnya lebih besar atau sama dengan $40^{\circ}$ biasanya daya mengalirnya kurang baik..$^{15}$ Aerosil berfungsi sebagai pelincir, sehingga jika tidak digunakan bahan pelincir tersebut dalam pembuatan granul maka kemungkinan granul tersebut tidak dapat mengalir bebas dan sudut diam yang terbentuk akan lebih besar dari $30^{\circ} .{ }^{5}$ Hasil uji evaluasi yang didapatkan menunjukan bahwa ketiga formula memiliki sudut istirahat yag baik yaitu dibawah $25^{\circ}$, untuk formula 1 sebesar $15,21^{\circ}$, formula 2 sebesar $17,17^{\circ}$ sedangkan untuk formula 3 sebesar $15,21^{\circ}$ nilai sudut istirahat dari ketiga formula tidak terlalu jauh hal ini terjadi karena jumlah aerosil yang ditambahkan pada setiap formula sama. ${ }^{12}$

\section{Indeks Pengetapan/Indeks Carr's}

Pengetapan merupakan penurunan volume sejumlah granul atau serbuk akibat hentakan (tapped) dan getaran (vibrating). Granul dengan indeks pengetapan kurang dari $20 \%$ menunjukan sifat alir yang baik. Indeks pengetapan dilakukan dengan mengamati perubahan volume sebelum dan sesudah pengetapan. Indeks pengetapan dilakukan dengan cara sebanyak 25 gram granul dimasukkan ke dalam gelas ukur, kemudian dicatat volume awal gelas ukur kemudian diketuk-ketuk sebanyak 100 kali hingga volume granul konstan. ${ }^{12}$

Hasil uji evaluasi ketiga formula tidak memenuhi syarat nilai indeks carr's yaitu untuk formula 1 sebesar $85,29 \%$ lalu formula 2 sebesar $32,4 \%$ sedangkan formula 3 sebesar $31,7 \%$ dari semua formula nilainya sangatlah tinggi hal ini terjadi karena granul yang dihasilkan tidak kuat dan mudah rapuh sehingga ketika dilakukan hentakan granul sudah menjadi serbuk. Penyebab granul yang dihasilkan mudah rapuh karena dalam formula penelitian ini konsentrasi vivapur 101 yang digunakan kurang. ${ }^{8}$

Uji Kerapatan Mampat dan Kerapatan Sejati

Kerapatan adalah massa per unit volume suatu zat pada temperatur tertentu. Sifat ini merupakan salah satu sifat fisika yang paling sederhana dan sekaligus merupakan salah satu sifat fisika yang paling definitive, dengan demikian dapat digunakan untuk menentukan kemurnian suatu zat. BJ nyata dapat dilakukan dengan menggunakan alat yaitu gelas ukur, dengan cara ditimbang bobot granul, misalnya 50 gram dimasukkan kedalam gelas ukur. Kemudian dimasukkan kedalam rumus sebagai berikut :

$P=W / V$

$\mathrm{W}=$ Bobot granul setelah ditimbang

$\mathrm{V}=$ Volume granul tanpa pemampatan 
BJ mampat dapat dilakukan dengan cara ditimbang bobot ganul yang akan dilakukan evaluasi, kemudian dimasukkan kedalam gelas ukur, dan lihat volume granul setelah dilakukan 100 kali katuk pada gelas ukur tersebut. Dengan rumus sebagai berikut :

$\mathrm{Pn}=\mathrm{W} / \mathrm{Vn}$

$\mathrm{W}=$ Bobot granul setelah ditimbang

$\mathrm{Vn}=$ Bobot granul setelah dilakukan pemampatan

Syarat untuk kerapatan mampat dan kerapatan sejati ialah $>0,21 \mathrm{~g} / \mathrm{ml}$, hasil pengujian didapat formula 1 sebesar $0,79 \mathrm{~g} / \mathrm{ml}$ lalu untuk formula 2 sebesar $0,625 \mathrm{~g} / \mathrm{ml}$ sedangakn untuk formula 3 sebesar $0,623 \mathrm{~g} / \mathrm{ml}$ artinya bahwa ketiga formula memenuhi syarat.

\section{Evaluasi Kapsul Ekstrak Daun Cincau Hijau}

Kapsul yang telah siap selanjutnya dilakukan uji evaluasi untuk memastikan seberapa efektif kapsul tersebut. Uji evaluasi yang dilakukan ialah uji organoleptis, uji keseragaman bobot, dan uji waktu hancur.

Tabel 5. Hasil Uji Evaluasi Kapsul Ekstrak Daun Cincau Hijau

\begin{tabular}{cccccc}
\hline No & $\begin{array}{c}\text { Uji Evaluasi } \\
\text { Sediaan }\end{array}$ & F1 & F2 & F3 & Syarat \\
\hline 1 & Organoleptis & $\begin{array}{c}\text { Sesuai } \\
\text { Persyaratan }\end{array}$ & $\begin{array}{c}\text { Sesuai } \\
\text { Persyaratan }\end{array}$ & $\begin{array}{c}\text { Sesuai } \\
\text { Persyaratan }\end{array}$ & $\begin{array}{c}\text { Bersih, Kering, tidak ada partikel } \\
\text { yang menempel dicangkang } \\
\text { kapsul }\end{array}$ \\
\hline 2 & $\begin{array}{c}\text { Keseragaman } \\
\text { Bobot }\end{array}$ & $1,4342 \%$ & $1,4184 \%$ & $1,4822 \%$ & $<10 \%$ \\
\hline 3 & $\begin{array}{c}\text { Waktu } \\
\text { Hancur }\end{array}$ & $\begin{array}{c}1 \text { Menit } 36 \\
\text { detik }\end{array}$ & $\begin{array}{c}1 \text { Menit } 50 \\
\text { detik }\end{array}$ & $\begin{array}{c}\text { 2Menit 20 } \\
\text { detik }\end{array}$ & $<15$ Menit \\
\hline
\end{tabular}

\section{Uji Keseragaman Bobot}

Berdasarkan persyaratan Farmakope Indonesia edisi III bahwa kapsul dengan bobot rata-rata lebih dari $120 \mathrm{mg}$ tidak boleh memiliki perbedaan dalam persen bobot isi tiap kapsul terhadap bobot rata-rata isi kapsul lebih dari $7,5 \%$ dan $15 \%$. Berdasarkan penimbangan kapsul untuk uji keseragaman bobot menunjukkan tidak ada yang menyimpang lebih dari persyaratan. Hal ini menunjukkan bahwa formula memenuhi kriteria untuk keseragaman bobot. Kapsul dapat memberikan efek terapi jika terlebih dahulu hancur menjadi partikel yang lebih kecil, agar isi kapsul dapat terabsorbsi pada saluran cerna.

\section{Uji Waktu Hancur}

Menurut Farmakope Indonesia edisi III syarat uji waktu hancur yaitu di bawah 15 menit. Hasil uji evaluasi diketahui bahwa formula 1 sebesar 1 menit 36 detik lalu untuk formula
21 menit 50 detik dan untuk formula 32 menit 20 detik artinya bahwa semua formula memenuhi syarat uji waktu hancur kapsul. ${ }^{16}$

Dari Hasil uji evaluasi diketahui bahwa sediaan Kapsul dari ketiga Formulasi semuanya memenuhi syarat di setiap pengujian, dan juga secara organoleptis kapsul bersih, kering, dan tidak ada partikel yang menempel pada cangkang kapsul

\section{KESIMPULAN}

Hasil Penelitian didapatkan bahwa Formula 3 merupakan formula yang paling optimal dilihat dari hasil keseluruhan uji evaluasi.

\section{DAFTAR PUSTAKA}

1. Santi I, Putra B, Wahyuni S. Uji Efek ekstrak etanol daun cincau hijau (Cyclea barbata Miers) sebagai anti inflamasi pada tikus putih yang diinduksi karagen. AsSyifaa. 2017;09(01):58-66. 
2. Angelina $M$, Hartati $S$, Dewijanti L, Banjarnahor S, \& Meilawati L. Penentuan LD 50 Daun Cinco (Cyclea barbata MIERS) Pada Mencit. Makro sains. 2008; 23-26.

3. Roselyndiar. Formulasi Kapsul Kombinasi ekstrak herba seledri (Apium graveolens L) dan daun tempuyung (Sonchus arvensis L). Depok : Universitas Indonesia,2012.

4. Depkes RI. Farmakope Indonesia. Edisi IV. Jakarta : Departemen Kesehatan RI, 1995.

5. Departemen Kesehatan RI. Farmakope Indonesia. Edisi III. Jakarta: Depkes RI, 1979.

6. Misna, Khusnul D. Aktivitas Antibakteri Ekstrak Kulit Bawang Merah (Allium cepa L) Terhadap Bakteri Staphylococus aureus. Galenika J Pharmacy. 2016; 2(2):138-144.

7. Nurmalasari DP, Antara NS, Suhendra L. Kemampuan Bubuk Ekstrak Daun Cincau Hijau (Premna oblongifolia Merr) Dalam Menstimulasi Pertumbuhan Lactobacillus casei subs p. J Rekayasa dan Management Agroindustri. 2017; 5(4):1120.

8. Siregar CJ. Teknologi Farmasi Sediaan Tablet. Jakarta: Penerbit Buku Kedokteran EGC, 2010.

9. Lannie H, Achmad F. Sediaan Solida. Yogyakarta: Pustaka Belajar, 2013.

10. Devi IA, Shodiquna QA, Eni NW. Optimasi Konsentrasi Polivinil Pirolidon (PVP)
Sebagai Bahan Pengikat Terhadap Sifat Fisik Tablet Ekstrak Etanol Rimpang Bangle (Zingiber cassumunar Roxb). J Farmasi Udayana. 2018;7(2) : 45-52.

11. Supomo, Bella D, Sa'adah H. Formulasi granul ekstrak kulit buah manggis (Garcinia mangostana. I) menggunakan aerosil dan avicel ph 101. J Trop Pharm Chem.2015;3(2).

12. Sa'adah , H., Supomo., \& Halono,M. (2016). Formulasi granul ekstrak daun kersen (Muntingia calara I.) menggunakan aerosil dan avicel ph 101. Media Sains Vol 9.

13. Reiza Z. Perbandingan Penggunaan Metode Granulasi Basah dan Granulasi Kering terhadap Stabilitas Zat Aktif Tablet Parasetamol (Skripsi). Surakarta:Universitas Muhammadiyah Surakarta, 2010.

14. Kibbe AH. Handbook of Pharmaceutical Excipients. 3rd. ed. London: The Pharmaceutical Press, 2000.

15. Voight R. Buku Pelajaran Teknologi Farmasi. Edisi V. Soendani Noerno Soewandi, translator. Yogyakarta: Universitas Gadjah Mada Press, 1994.

16. Nurani L, Kumalasari E, Rohman A, Widyarini S. Formulasi Kapsul Ekstrak Etanol Akar Pasak Bumi (Eurycoma longifolia Jack) dan Pengaruhnya terhadap Vital Sign Manusia Sehat. J Tradisional Medicine. 2017 Agu;22(2):91-96. 